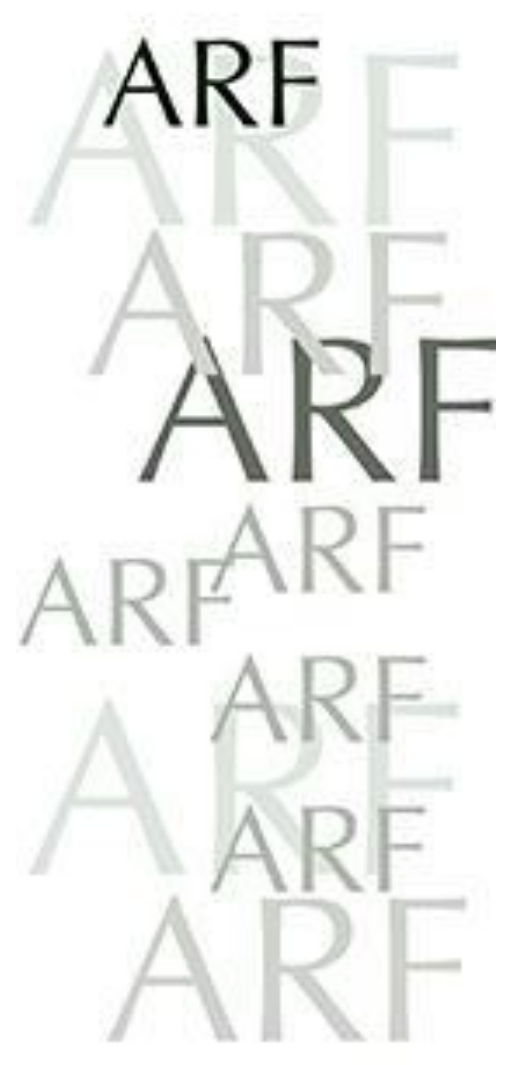

Based on

a narrative approach, this contribution analyses

a personal life journey to discuss the relationships between architecture, city and home.

\section{Architecture, City and Home: A Personal Narrative of a Globetrotter}

\author{
Karine Dupre \\ Griffith University, Australia \\ k.dupre@griffith.edu.au
}

\begin{abstract}
Based on a narrative approach, this contribution analyses a personal life journey to discuss the relationships between architecture, city and home.
\end{abstract}

Keywords: home, city, architecture, narrative research

\section{Introduction}

There is an abundant scholarship on what is home (Moore, 2000; Somerville,1997; Lawrence, 1995; Saunders, 1989), the meaning of home (Benjamin, 1995; Smith, 1994; Sixsmith, 1986;) and how architecture shapes the walls and roofs of our homes. Likewise, many have already written about the role of the city in providing the infrastructures and services needed to secure a strong sense of attachment, safety and homefeeling (Le Corbusier, 1924; Jacobs, 1961; Newman, 1996). I am afraid this is not what this paper is about. Rather than contributing further to this scholarship in a conventional way, I prefer to invite you to a small journey regarding the places I call home. As I have been lucky enough to live and work in different parts of the world, I believe that this exercise, run in parallel to my awakening to architecture, might provide some global views on the topic of home. I also hope it may inspire some further research into narratives of homes. I acknowledge that this contribution is incredibly biased as it is about my life story. Any resemblance to actual events, to places and to persons living or dead, is not a coincidence.

Welcome to my journey!

\section{Setting the context}

I am French, from the country of the Enlightenments, the existentialists, the avant-gardists, the Arts, built heritage and innovative architecture! Alas, as much as I would like to tell how much I gained from this great environment, the truth is that I was born in a lower middle class family. Thus my education consisted mostly in what school delivered at that time (which I think was a good basis), and the systematic visit of castles and churches in a different region of France every summer, which I came to hate with all my heart as a teenager... Truly, although tourist guides must have been talking about architecture, the word remained a blank concept. I could only see old stones.

The earliest memory of home I have concerns the apartment we moved in when I was three, in a suburb $18 \mathrm{~km}$ west of Paris (Figure 1). Part of a social housing pyramidal complex built in the early 1970s to house a diversity of people from the former French colonies, it included up to 17-floor buildings with a typomorphology that highly contrasted with the rest of the town and was framed by two motorways on its north and west side. The complex looked huge to me 
and I guess it was, with 1400 apartments housing 4,500 new residents, which represented $30 \%$ of the town population at that time (SOAinfo, 2016).

Home was a three-bedroom apartment where I lived with my parents, little brother and uncle, until the latter moved away. I remember the large glass windows bringing a lot of light into every room, the tall exotic plant in the corner of the living room, the narrow kitchen with a cold storage room and the door to the balcony where we were not allowed to go. But I also remember the square threshold without any natural light before entering home, where the light would turn off automatically, pushing my brother and I in a frantic panic whilst waiting for my mom to come home and open the door.

Home was this place, whilst the outside world was limited to the pedestrian path leading to school and back. It felt so far away and it was only $300 \mathrm{~m}$. It was always an adventure when my brother and I were allowed to visit my grandpa, alone, who was living in the same complex but in another building. We were proud as peacocks, yet we would hold our breath and run like crazy through the dark, foul smelling tunnel that led to his home. Other than this escapade, I clearly remember we were strictly not allowed to play outside, even though all the apartments had a view on the central green corridor. It is my first recollection of safety issues, strongly generated by the racism of my father.

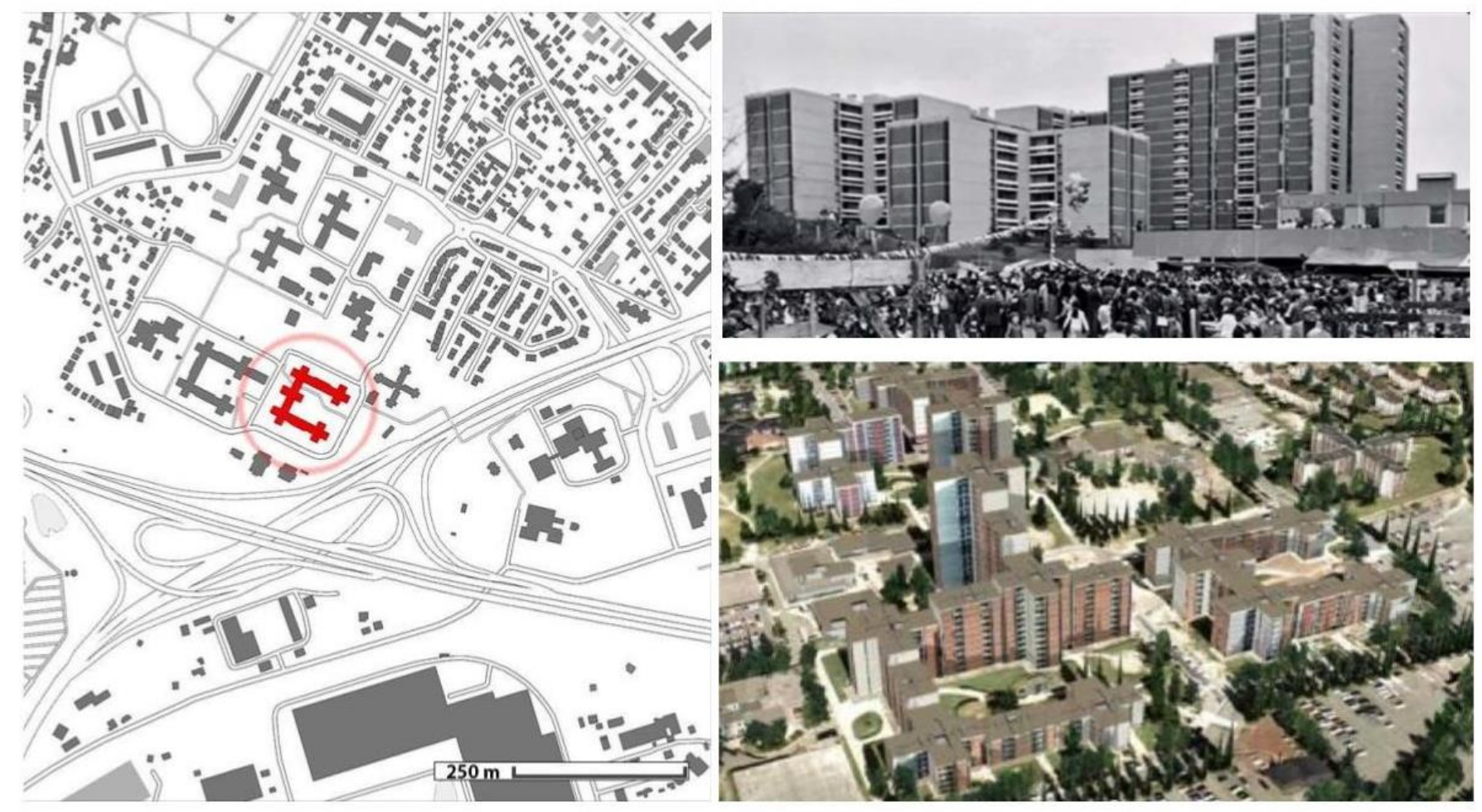

Figure 1. Saint Ouen l'Aumône (France): urban fabric and archival pictures of the housing complex.
When I was ten, my parents bought their first apartment just $10 \mathrm{~km}$ away from Saint Ouen l'Aumône, in Beauchamp, a town of 8,400 residents in 1980 (INSEE, 2019). Climbing up the social ladder, we moved into a smaller apartment complex, only three storeys high, adorning fancy triangular balconies with brown tinted glass. This home was both smaller and bigger, as we had lost one bedroom but the living room was twice as big (Figure 2). Otherwise, it remained quite similar to me but for a basement garage, and the surroundings, much more well maintained.

Further climbing the echelon of middle class, we lived in the only block of luxury flats in this residential neighborhood that mostly consisted of private individual 
houses. It was the first time I was confronted with children who were not living in an apartment: almost all of them were living in their own house with their own garden and fruit trees. Our apartment was surrounded by greenery as well; you just weren't allowed to step on it. School was $750 \mathrm{~m}$ away but still felt further away.

It was also around this time I became aware that going skiing during the winter holidays was a privilege validated by your tan, as was going somewhere during the 2-month long summer holidays. One kid or two stuck out due to their colored skin, but the social homogeneity prevailed in this quiet, relatively wealthy, and well managed suburb. My perimeter of investigation gradually expanded as I was growing and so changed my mobility. I started to bike to reach middle school which was located $1.5 \mathrm{~km}$ away from home, yet the journey was still very controlled by the ruling of my parents. I varied very little from what had been indicated as the safe way.
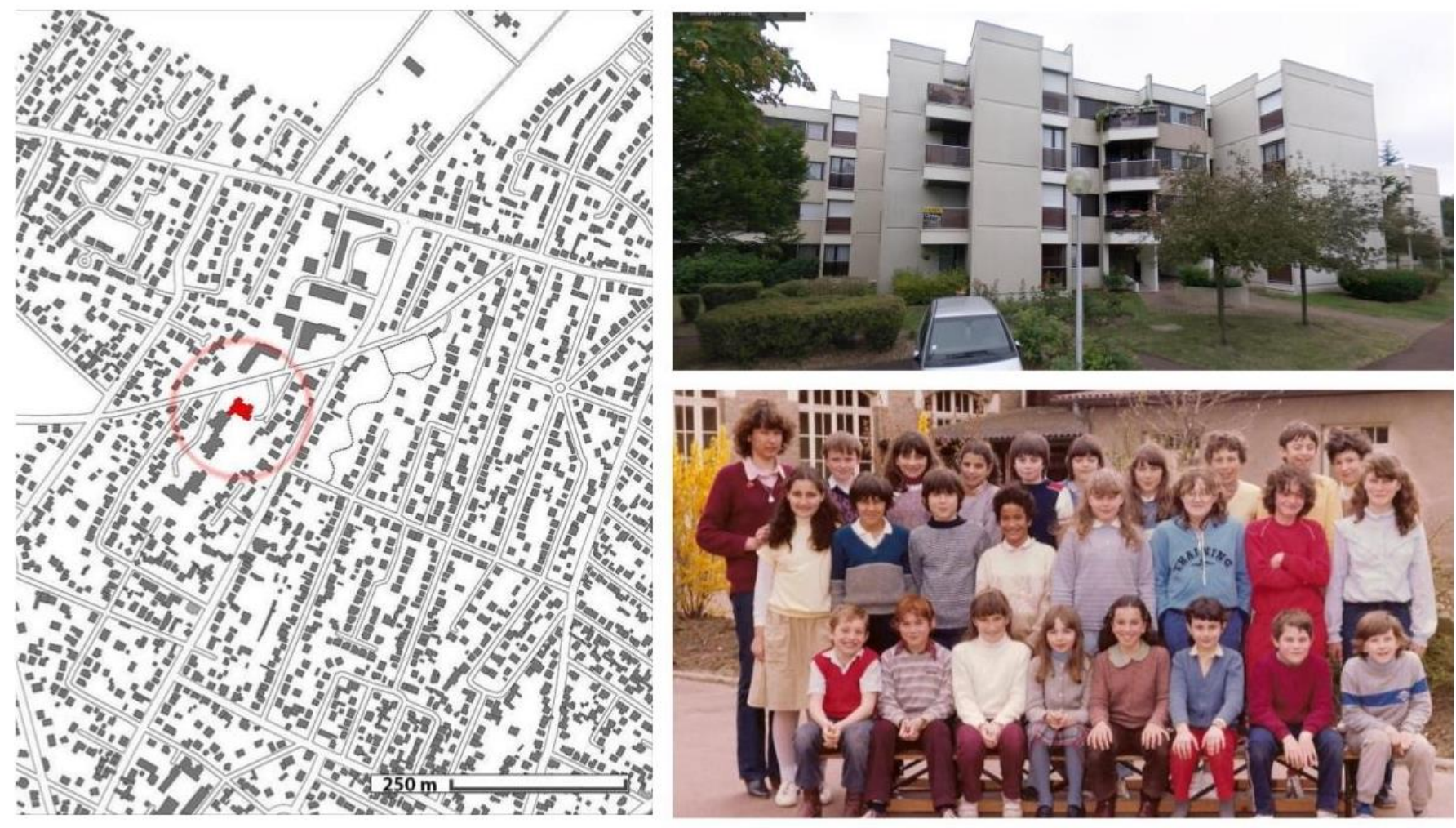

Figure 2. Beauchamp (France).

At last, my parents bought an individual house in Mery-sur-Oise, still $25 \mathrm{~km}$ west of Paris, where we moved when I was fifteen (Figure 3). My brother and I each had our own bedroom for the first time, and an immense garden $\left(1500 \mathrm{~m}^{2}\right)$, with cherry, apple, and walnut trees. This was the dream of the average French family, so well described by Bourdieu (1979). Built in 1928 with millstone walls, the house also included an attic that would be later converted into two new bedrooms and one bathroom. I loved this home! The only problem was the setting and the distance.

What maps are not showing is the steepness of the main street (12\%) and the countryside feeling: fields everywhere...old people everywhere, a street without children: we had ended up in a gentrified town, one which was slowly dying. The city consisted mostly of one main street and one town center, more or less well kept, and many residential areas, quite protected from the crimes of the bigger cities. Basically, we were living in what resembled one of our holiday places, only at the outskirts of Paris. Everything felt so far away. My high school 
was $6.5 \mathrm{~km}$ away, which I would travel to by the means of one of three routines; walk-train-walk or walk-bus-walk or by bike. Whilst the two former were most inconvenient, the latter was the most favoured, not having to deal with the unreliability of public transport (traffic jams, strikes). However, this inconveniency gave me more self confidence in exploring my extended environment. Despite loving the building of my home, I was left dreaming of escaping this neighborhood, consequently leaving as soon as I graduated from highschool.
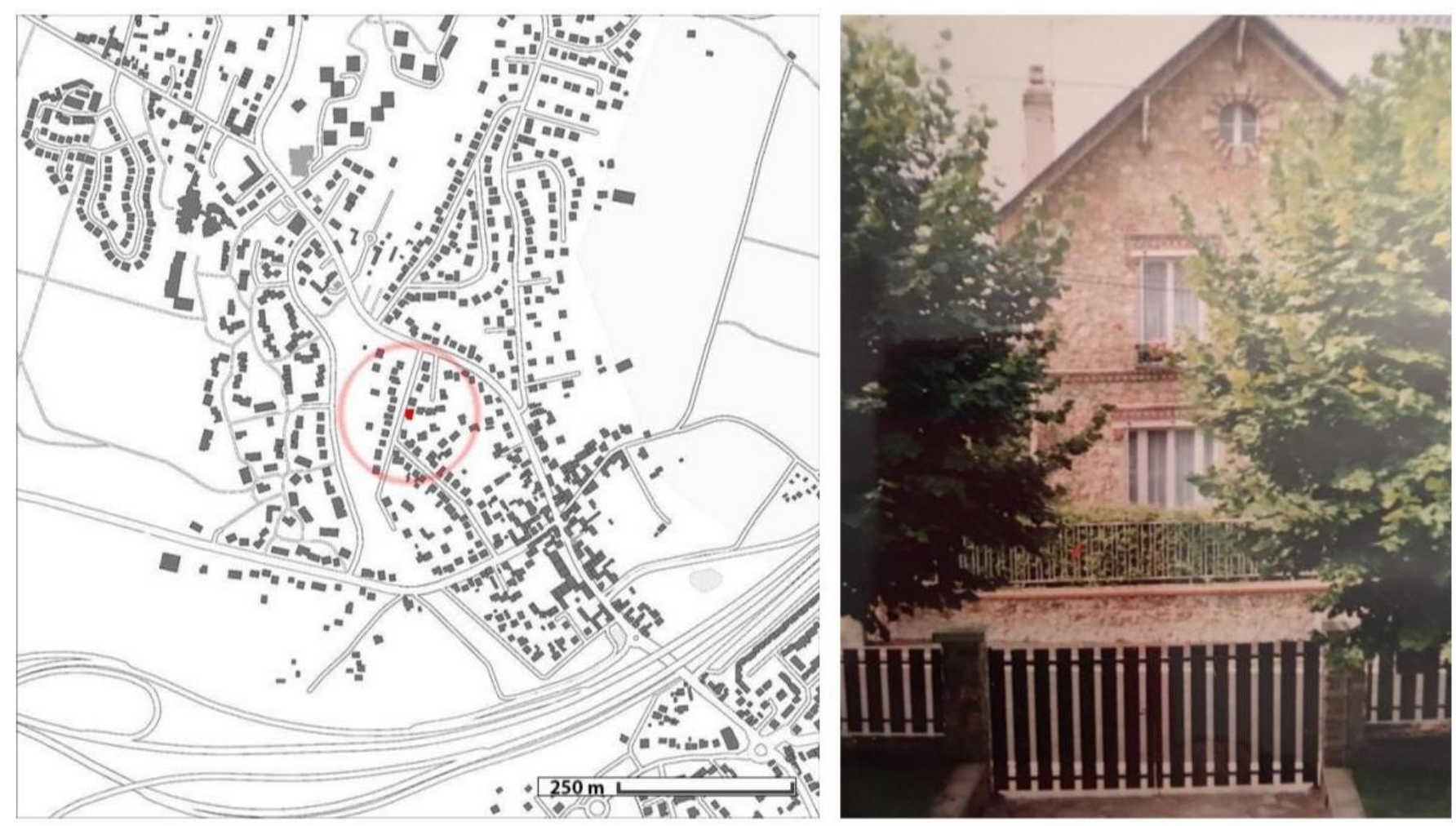

Figure 3. Mery-sur-Oise (France).

\section{Formative years}

Starting as a student of medicine, I moved to the northern area of Paris in the Gare du Nord district, an area totally rebuilt by Haussmann in the mid 19th century (Figure 4). Although I felt that I had always lived with a certain level of social mix, my new home proved to be quite a step up in that matter. All my neighbors were from Africa, India and Bangladesh; shops had signs in a language I could not read. The smell of spices that I never encountered before was permanent in the building' staircase; sheep were kept in the bathtubs before Ramadan. I was living in another world, sharing one toilet with at least five other families.

But I was in Paris, walking and walking, curious about everything! I experimented with the cold winds of Jussieu, the post-May 1968 built university intentionally designed to discourage student gatherings. I experienced density, mixed uses and the large faubourgs of each Parisian district that all had such a distinctive identity. And so many opportunities, everywhere. I was constructing my own mental map of Paris, not knowing yet of the work of Lynch (1960), with personal landmarks: my university, a bakery here, a museum there, etc. There were no limits to my curiosity, mostly by foot, bicycle, and public transport. Paris was not especially clean, but I never felt unsafe, although there were obvious changes of ambience at night. For the first time also, I experimented with the metro, its smell and the diversity of people. Tourists, beggars, drug addicts, homeless people! 

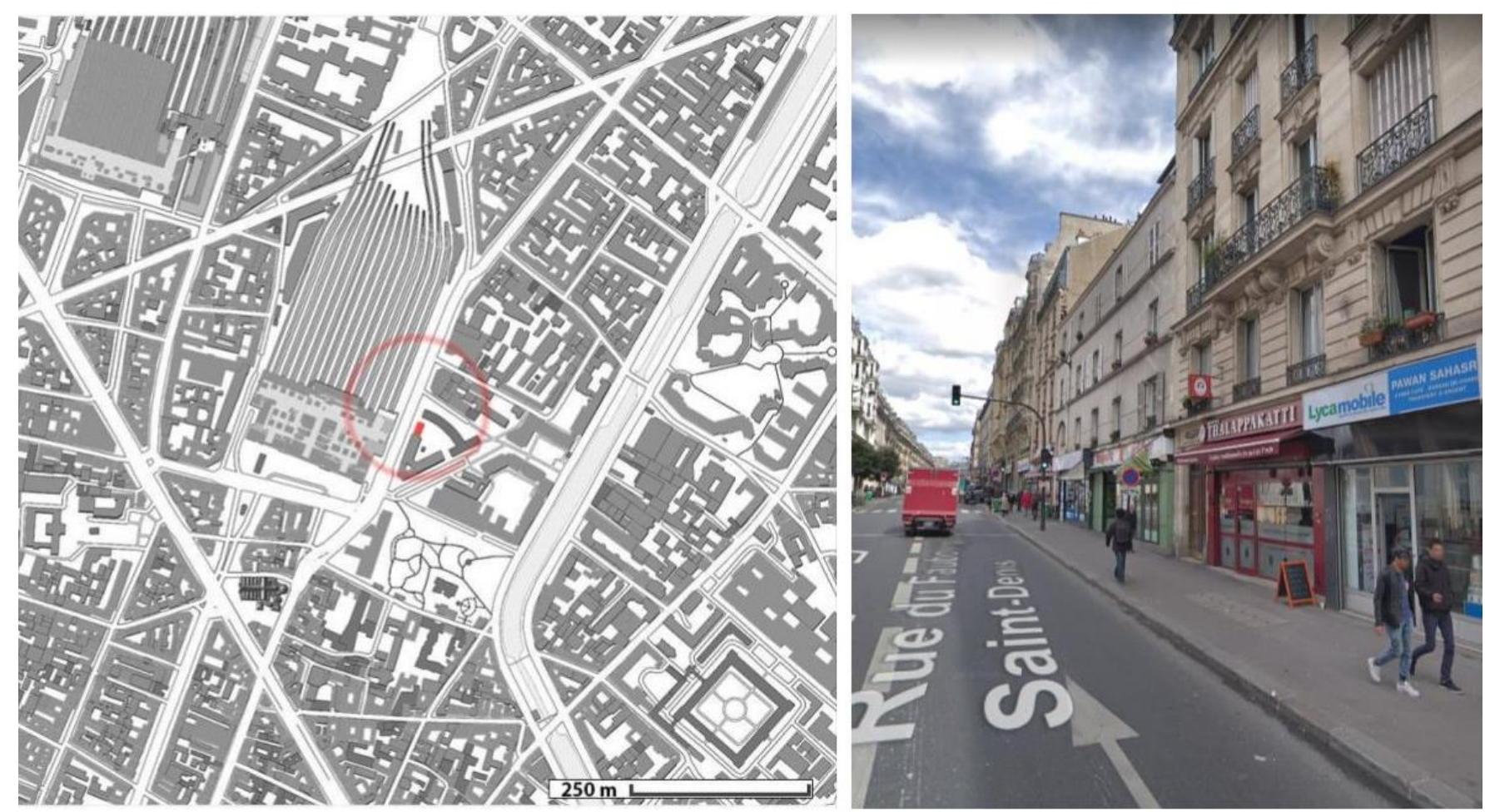

Figure 4. Paris (France).

Admittedly I was absorbing all quite randomly, until I started studying architecture. My five years of architecture studies actually gave meaning to what I was seeing. It also gave a goal to my wandering as we were given specific tasks and briefs. For example, we had to sketch and analyse the threshold between public and private spaces, analyse the urban context of a park, imagine a new building in a specific district, etc. It literally opened my eyes to my surroundings and to architecture itself. It added a new layer to my personal map of Paris. This included historical buildings, contemporary buildings and districts to become.

During this time, due to my very limited income, I moved back to the immediate outskirts of Paris in places that offered cheaper rents and walking/ biking proximity to my university. The first place was in Vitry-sur-Seine (Figure 5, top), the bastion of communism with large blocks of flats built in the post World War II reconstruction period, that would accommodate families from multiple and diverse backgrounds (Vitry94, 2019). I can remember the multitude of languages being spoken at the Sunday market, whilst in my home alone, three were already spoken (French, Arabic and Spanish) because of the nationality of my roommates. I lived in one of those immense buildings on the main boulevard, with the big supermarket and public transport being conveniently placed right at my doorstep. In 1994, this city of 82,000 residents (INSEE, 2019) offered many services for its youth, which I took advantage of. However, I had to find another place when my roommates separated.

Bordering Paris through the peripheric, Saint-Mande was on the other hand characteristic of a bourgeois and Haussmann built environment, with an ageing population (Figure 5, bottom). The town of 19,000 inhabitants in 1997 (INSEE, 2019) was much cleaner and smart-looking due to its impeccably maintained built heritage, yet I felt it offered little for people of my age and income. Maybe it was due to the proximity of Paris that offered so many activities? However, the travel bug had got hold of me and I worked my way to leave as an exchange student for a very exotic place, where no one wanted to go: Finland! 

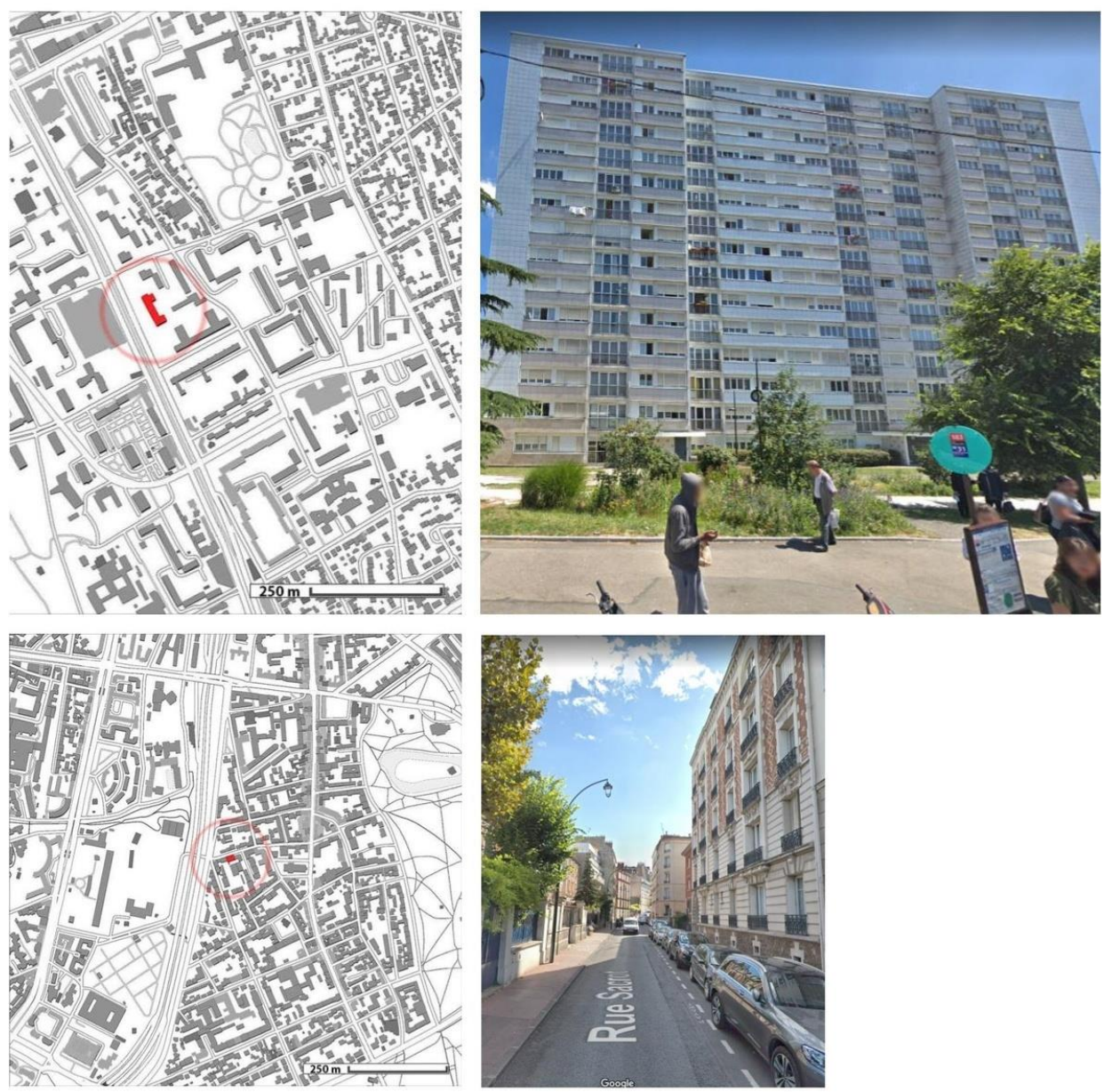

Figure 5. Top: Vitry-sur-Seine (France), bottom: Saint-Mande (France)

So I moved to Finland, Tampere more specifically (Figure 6). What a cultural shock! Please forgive my ignorance at the time. I didn't have a single preconceived notion about the country because I knew nothing about it. My first interaction with Tampere is still very vivid: it was in July 1995, long beautiful days, and large streets... empty, with almost no traffic. Big motorway junctions and no traffic. Shops with only one brand of soap or milk. I could not believe my eyes that supermarkets had microwaves for customer use and no one was stealing them! Remember, this was the time when Finland had just joined the European Union and debates were raging on whether it was a good choice or not.

I was surprised to see drunk women peeing in the street at night time and fishermen in the middle of the city during the day. And most importantly, I had never seen buildings that looked this way. To me, they resembled those of Disney movies, with their yellow walls and red roofs, or looked like my idea of Russian architecture: grey blocks standing alone in the middle of vast green areas.

I was living in a tower-like building called Uusi Domus, discovering the joys of student accommodation, including poor sound insulation, but also a shared sauna, TV room and laundry room. Once again sizing the territory by foot and bike, I was looking for places that felt more rooted and human to me, with which I could relate. Tallipiha and Finlayson were some I found. These places had history I could read and feel. I also discovered new types of discrimination (e.g. racism against Romani people) and issues I had never been confronted with before, such as the impact of natural light on people's mood, binge drinking, the 
positive aspects of welfare state and its lack of empathy (remember the Yugoslavian refugee scandal in 1998?).

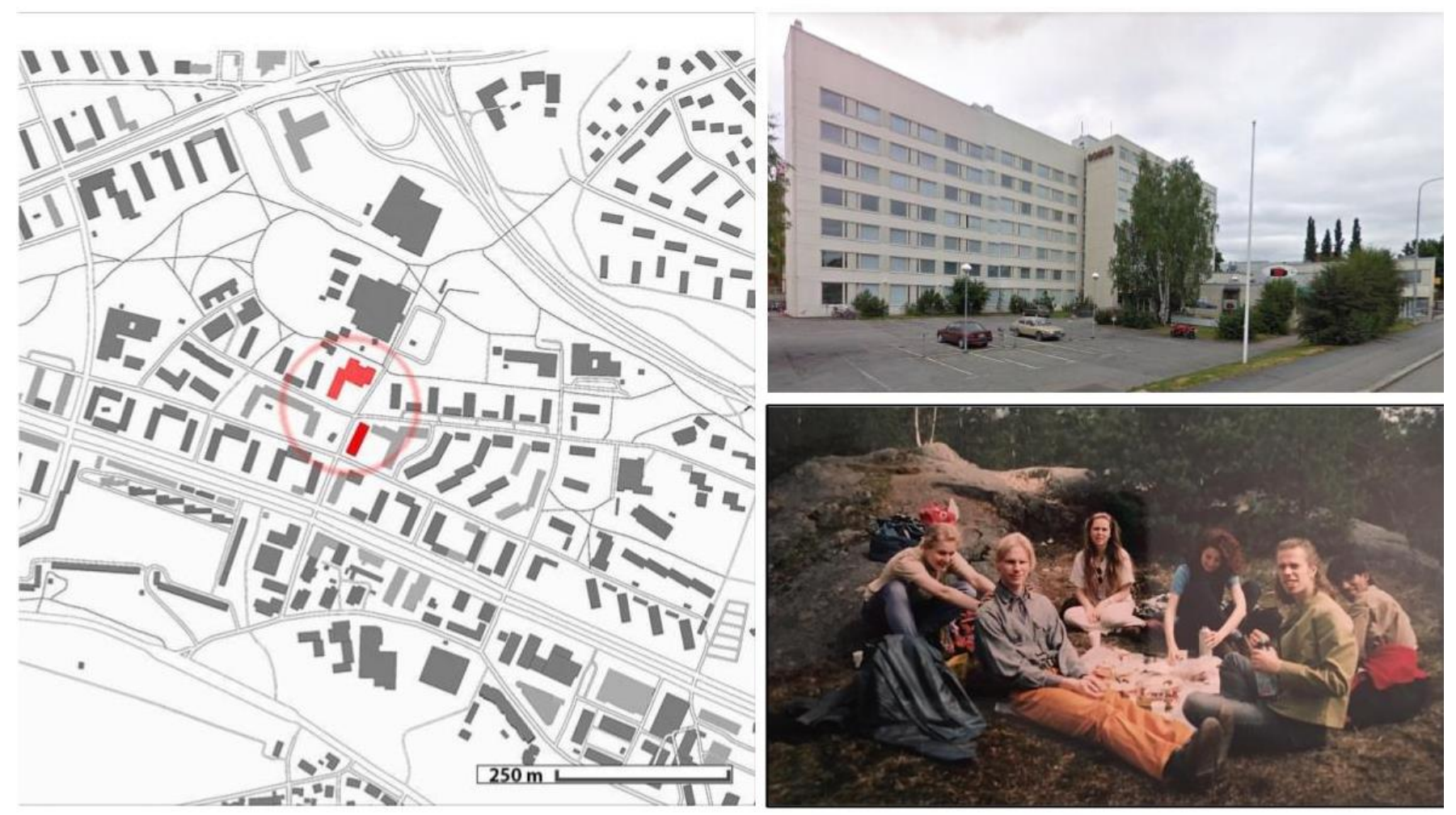

Figure 6. Tampere, Uusi Domus (Finland).
Despite being confronted to architectural students who were ten times better than me and ten times more efficient (no charrette!), I fell in love with the country and my husband Pasi. For me, this place had all the ingredients to start a family: safety (parents can leave their baby in a pram outside shops), good transport services, an incredible amount of public spaces which double in winter time with the freezing of the lakes; small enough territory to feel legible and entitled.

Retrospectively, it is also not a surprise that we bought a 1937 house in Pispala (Figure 7). It was loaded with history that both Pasi and I are fond of, and it was cheap so we could afford to renovate it entirely by ourselves. However there were also other criteria. Everything we needed was around, at a walkable distance: the day care päiväkoti $(700 \mathrm{~m})$, the early childhood health centre neuvola $(1,200 \mathrm{~m})$, the supermarket $(400 \mathrm{~m})$, the bus stop $(20 \mathrm{~m})$, the lake $(300 \mathrm{~m})$, and, very importantly for Pasi, Rajaportin sauna $(700 \mathrm{~m})$. It was exotic for me to bring my children to päiväkoti with a sledge!

Besides being a famous tourist precinct, Pispala offered a real community environment where people got to know each other. Maybe its historical activism and the fact that my beloved Pasi was the president of the Pispala resident association contributed to our integration, but most importantly I developed, maybe for the first time, an interest in district activism, outside the limits of my home. It mostly included the maintenance of the community garden and protecting it from being redeveloped into a housing estate, as we had witnessed just next door. We were also the proud owners of an electric car that I used for my daily trips to the university located in Hervanta. 

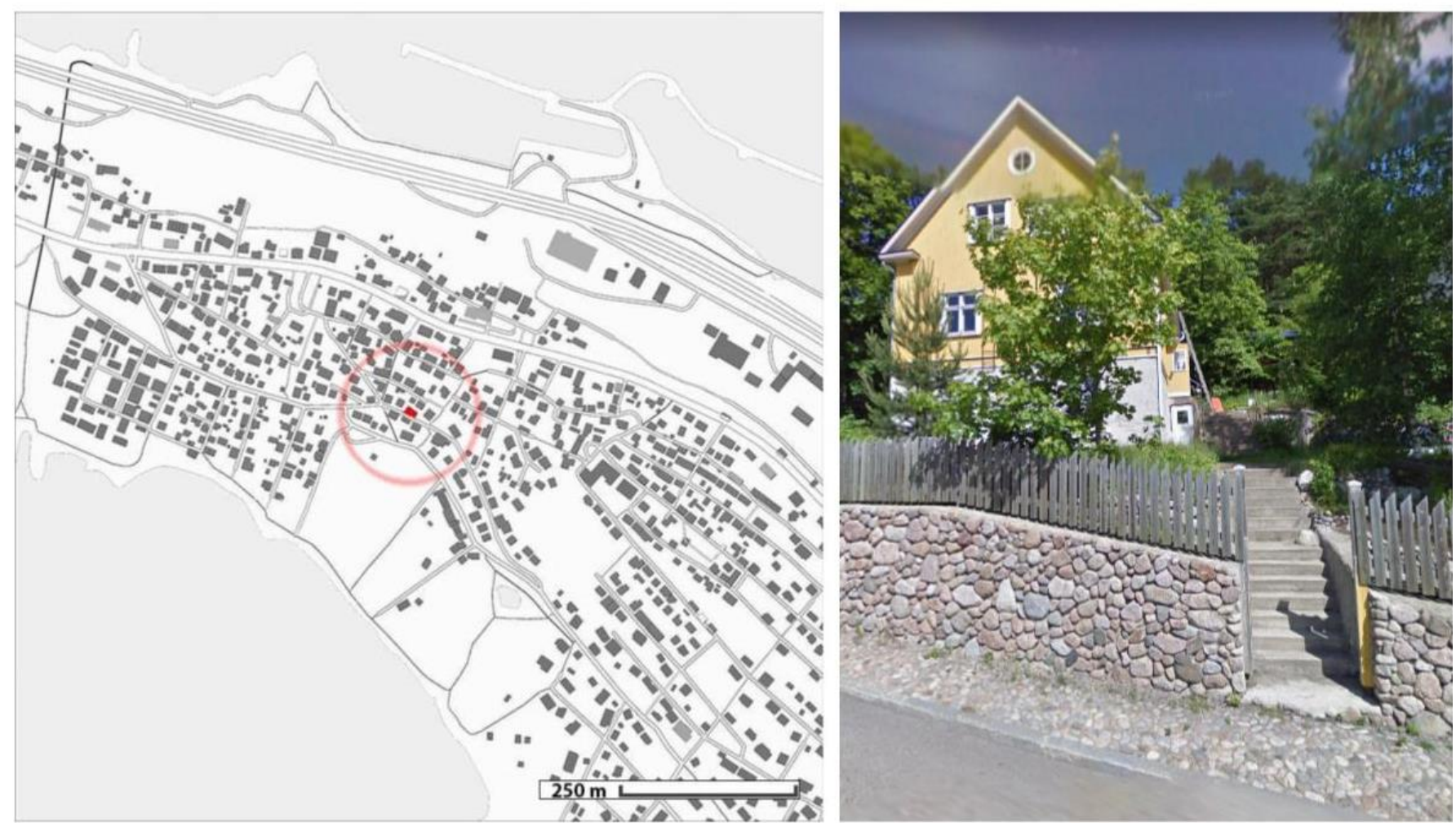

Figure 7. Tampere, Pispala (Finland).
My studies gave us the opportunity to live for a year in Gosier, a French small town in the Caribbean where I was studying for my PhD (Figure 8). The contrast with Tampere was startling: it was basically all the opposite of Finland, not only due to the tropical climate but also all the flaws that constituted the town. Disorganised public transport, missing facilities, rundown buildings, derelict university, corruption, and informal settlements with many crimes were dominant. Yet, rich colours and greenery were abundant; history poured everywhere, not only in buildings but in multiracial relationships, with a significant importance given to verbal exchanges, all constituting the urban life on the island of Guadeloupe. For the first time, we (my husband, my two children and I) were a minority, due to our skin color, and deeply immersed into inequality as we lived in the informal settlement I was studying. We witnessed health, socioeconomic and educational inequity and vulnerability, and social injustice.

This provoked emotional and moral debates: feelings of rejection, guilt in relation to the colonial past and powerlessness to help. We also experienced distancing from family and known places, which affected our identities and capabilities. In Guadeloupe, I at first sight was assumed to be a Zoreille (which is a nickname given to mainland French workers), due to my physical appearance. Yet working on the nearby island of Martinique, I was Chabine, a racial category that implies that at least one of my ancestors was a colored person. However, what 'saved' us in terms of relationships with locals was the fact that Pasi did not speak well French at that time, so we could not possibly be from France. We lived in an informal settlement that had been partially renewed. Our district was a labyrinth well controlled by its inhabitants and every day coming home from work, I knew exactly what Pasi had done during his day as all the neighbours, one after the other, would tell me.

Back in Finland, it was difficult to remain there knowing what we lacked: social connections. Despite our beautiful Pispala home that had turned into a community during our absence, the Finnish mal de vivre was too heavy. And so, 
our journey to France and Australia started. I was not a student anymore, we were a little family on the move.
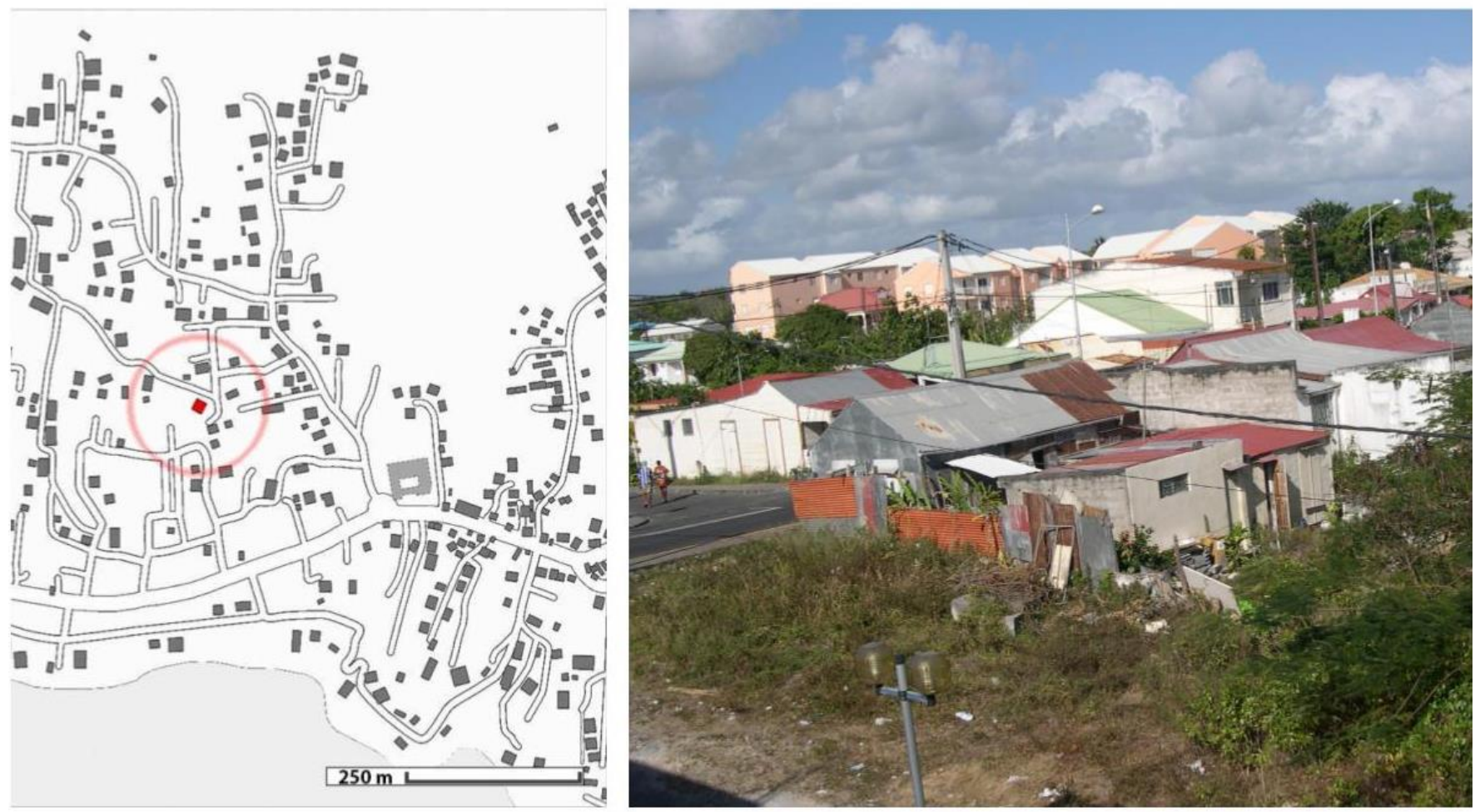

Figure 8. Gosier (Guadeloupe).

\section{Adulthood}

At first, we moved to Nantes, a town in the West of France with a very long history and extensive architectural heritage (Figure 9, top). The sixth largest city in France, it offers a strong urban structure with the first tram being reinstalled in 1986. We moved there with only two cubic meter of books and found a place that corresponded to our values. Proximity to school and leisure opportunities were prioritized as well as walkability. It was a voluntary adult choice both for sustainability, to reduce our footprint, and to make our lives easy. Our home was in a residential area, among like-minded people. We fitted in easily, quickly making a lot of friends, although our tiny $56 \mathrm{~m}^{2}$ flat, built during the reconstruction of Nantes after World War II, was certainly contrasting with the standards of this community. As I got a new job, we moved to the other side of France.

Strasbourg, east of France and bordering Germany, had an even richer history, but basically presented the same assets: a clear urban structure, well maintained, and urban projects to bridge the territory with Germany. We also settled in with the same walkability principles. The only difference is that we got to build a new home (Figure 9, bottom), a passive house inspired by what we did and learned in Finland. Strasbourg has always been an avant-garde city regarding sustainability and ecological environment within France, and proved to be fertile ground for our project. This house was exactly our perfect house, entirely built by Pasi.

Yet, I never liked the city: there was a tension in the air that made me uncomfortable, and unfortunately made many headlines, specifically regarding racism. Social injustice is visible in the urban fabric as there is also a clear contrast between ultra-rich neighborhoods, where all the European union members are living and working, and others, mostly inhabited by low-income 
people. Eventually, when our daughter got physically attacked fifty meters from home by a gang of girls, there was no doubt we were leaving. I found another job in Australia at that time.
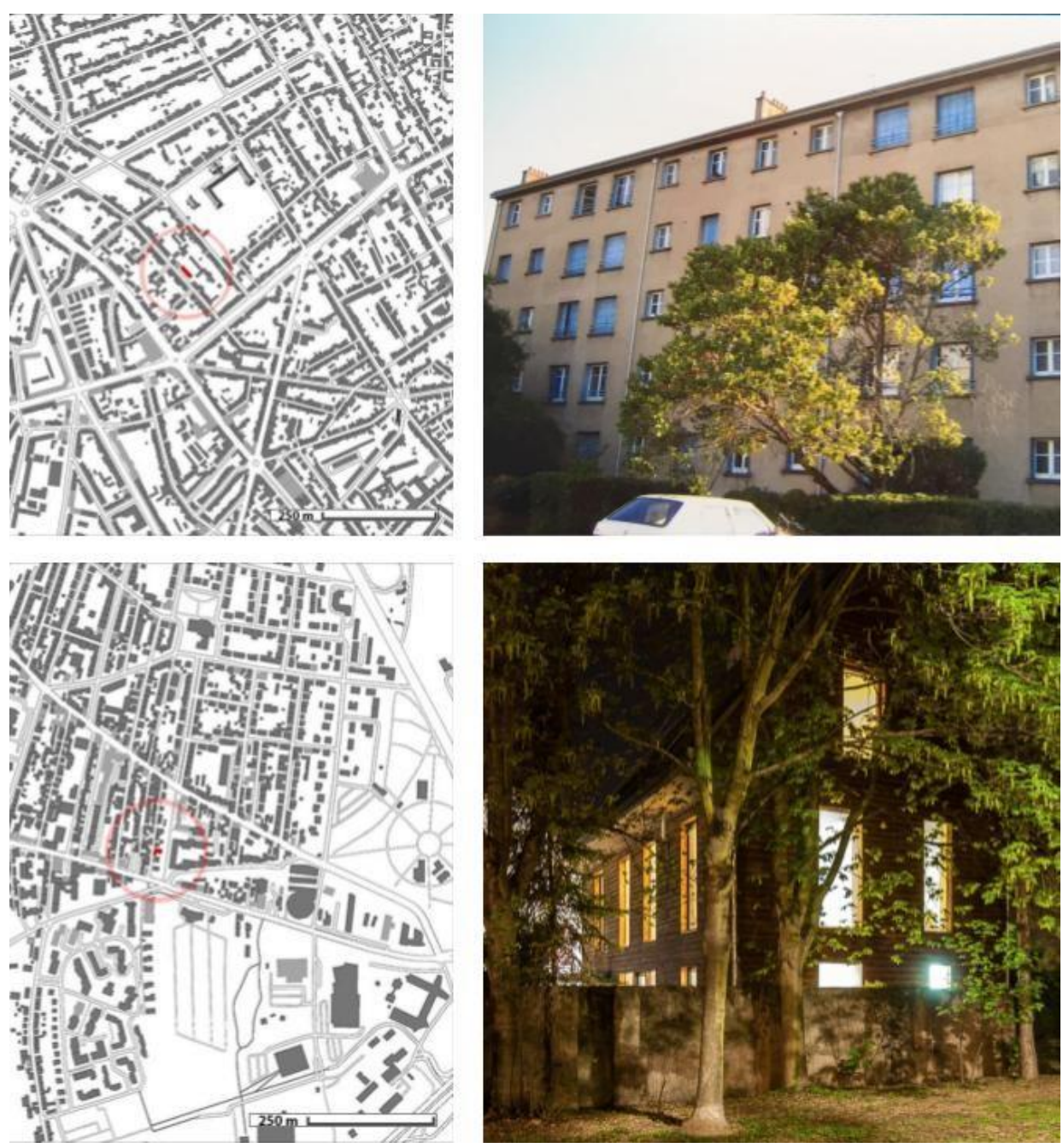

Figure 9. Top: Nantes (France), bottom: Strasbourg (France)

We moved to the Gold Coast, the sixth largest city in Australia on its east coast, and the place of our current home (Figure 10). Do you know this feeling 'It looks like it, it tastes like it, but this is not the real stuff'? It was another cultural shock. Although the city looked very familiar in terms of existing infrastructures, services and landmarks, there was a major difference with the European cities that I had experienced so far: the spatial organisation did not follow the traditional patterns of development.

The Gold Coast is a car-oriented city, a strip with no real town centre but rather a series of small hubs. The wording 'town centre' is often used to name shopping malls, not real public places. Similar to one of Koolhaas' suburban pictures (1995), districts developed and still do without connections to a historic centre, since, as a matter of fact, there is no heritage older than the late 19th century. Besides, renown for a very fast pace of change (Bosman et al., 2016), the built environment of the Gold Coast is also characterised by new buildings being erected in place of 'older' ones, for which few people had time to create memories with. From a pedestrian point of view, the hot temperatures make it twice as dangerous to walk on the streets without sidewalks. As such, it was very difficult to find a place that met our walkability expectations, and once we did, we were 
shocked by the unreliability of public transport. Luckily, the construction of the tramway and its opening in 2014 changed this aspect. The other major difference with all the other places we had lived in concerns the privatisation. It feels like every space is privatised, leaving only one truly public space: the beach. This is actually where major celebrations take place.
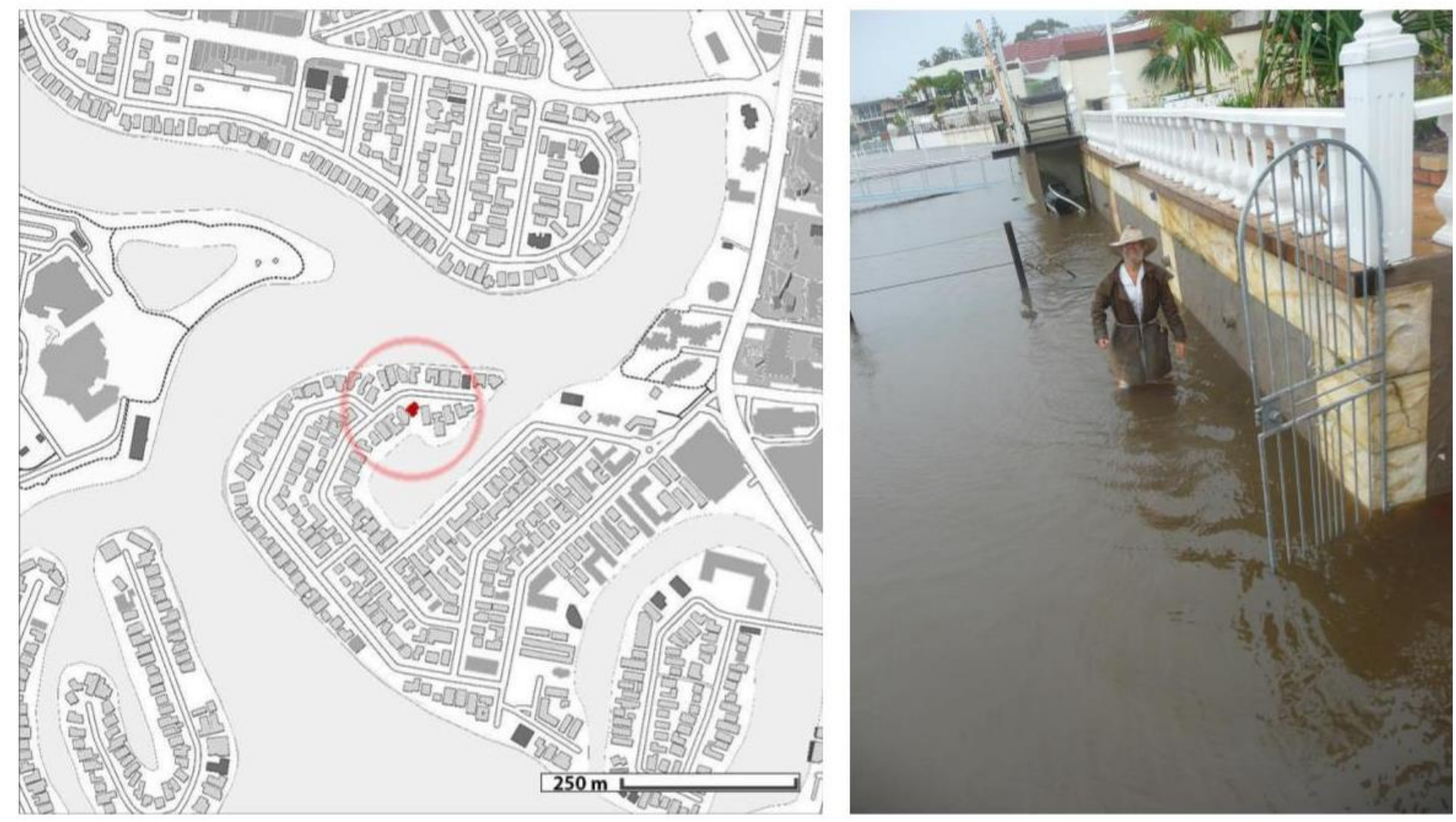

Figure 10. Surfers Paradise (Australia).
However, on a more positive note, this is the place where I got introduced to a real reflection on the meaning and construction of a qualitative tropical architecture. Although Australia is not really famous for its energy efficiency and ecological positions, many projects (whether small or big, private or public) address the challenges of sustainable living in the tropics. For example, maximising un-air-conditioned spaces through building orientation, wind flow and maximised shading; or creating generous outdoor living spaces and high quality landscaping as we experienced with our home. Furthermore, there is no argument that climate change is experienced everyday in Australia as natural disasters often strike the country and endanger its population and economy. I confess this is the place where I became the most aware of it, not only because of the cyclone of 2013 that welcomed us when we settled in, but because of the yearly floods, droughts, cyclones and fires.

From a cultural perspective, similar to Guadeloupe, I observed social injustice, with the ongoing issue of not recognising the rights of the First People that permeates the society's social changes (or lack thereof). At the same time, the ban of guns and a very high level of health and safety laws have resulted in one of the safest countries in the world, which I acknowledge daily and appreciate even further with teenage children. Interestingly, wellbeing is a hot topic in architecture and planning in Australia, as well as healthy ageing. I had never encountered such a strong interest in the latter topics elsewhere. 


\section{I was telling you how biased this contribution will be since the emphasis is on my life story. In reality, I have not been fully honest with you, as I actually used several methods to present this story and analyse it.}

\section{Discussion}

As you may remember, at the start of this paper, I was telling you how biased this contribution will be since the emphasis is on my life story. In reality, I have not been fully honest with you, as I actually used several methods to present this story and analyse it.

Firstly, I used the narrative approach, which is a research method, often used in social sciences. It studies the experiences of a single individual as well as the meaning of these experiences (Lieblich, 1998; Carless and Douglas, 2016). I hope the previous sections provided a good example of how valuable this can be. While describing the different places I lived in, I could decipher my growing understanding of architecture and planning.

Secondly, I used typo-morphological analysis with the help of Nolli maps to read the different urban fabrics in which I lived. I find the results eloquent. For example, we can easily read the dormitory nature of the first three towns of my childhood (Figure 11). In the same way, it evidences the misconception that segregated large housing programs would be an innovative solution to housing issues. Forty and fifty years later, all these large programs have failed without exception. They are currently facing or have already faced heavy restructuration to break down the ghettoization, create better connections with the rest of the city, and provide the same social opportunities to its residents. Restructuration is currently underway in Saint Ouen l'Aumône, and also in Vitry-sur-Seine.

\section{AND SO WHAT?}

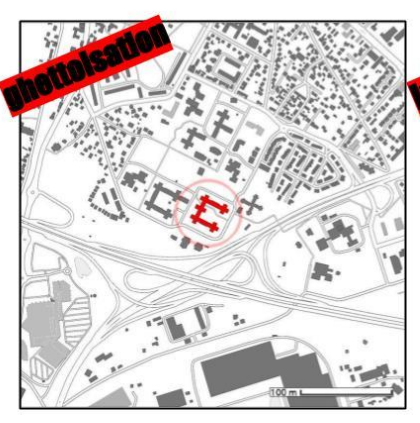

Social and spatial segregation

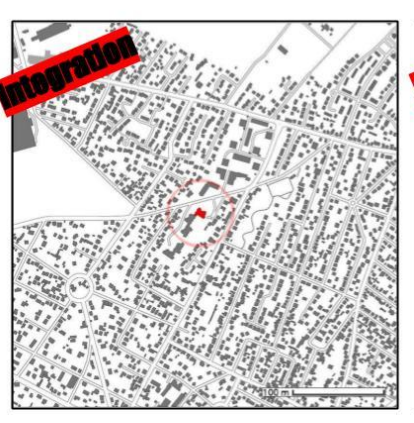

Social homogeneity and spatial redevelopment

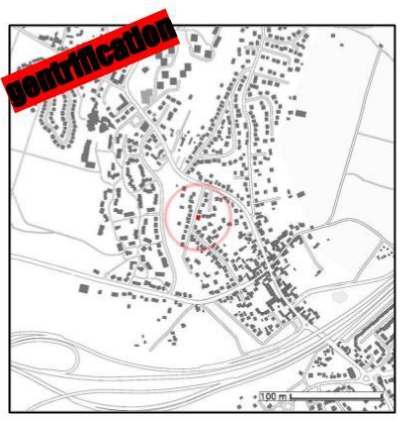

Social homogeneity and spatial rigidification

\section{DORMITORY SUBURBS}

These maps also help to understand the role of history and the different layers it added to the development of the city (Figure 12). They also show how the diversity of programs, such as housing, businesses, retail, transport, etc. participates to the diversity of the urban experience, to the city's dynamism and often to a better enjoyment. Opportunities are key in this type of setting, because once they fade away, the area identifies as a dormitory suburb as the case of Saint Mande shows. Yet for many residents of Saint Mande, home is there because it is cheaper and the city offers all the advantages of Paris without its flaws.

The analysis also shows that one can experience otherness, yet urban fabric and processes repeat themselves, here and there, demonstrating a universal call for the way we inhabit and we develop our environment (Figure 13). For example, Pispala was also a type of informal settlement area before it became an attractive place for better off people. 


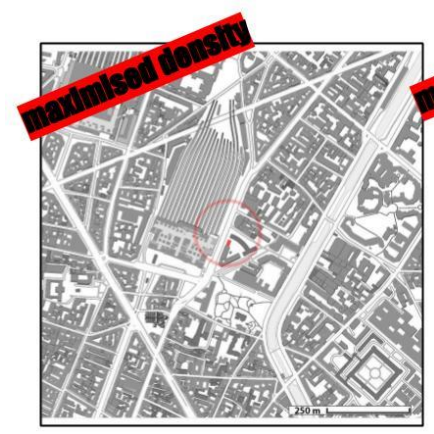

Social and spatial diversity

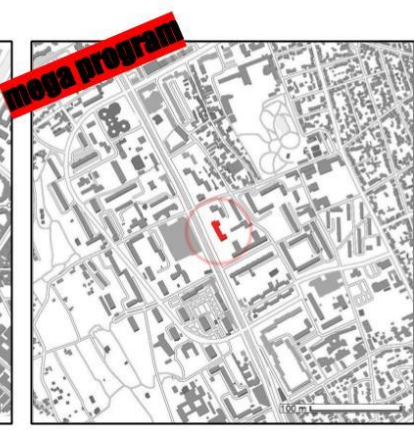

Social diversity and spatial homogeneity

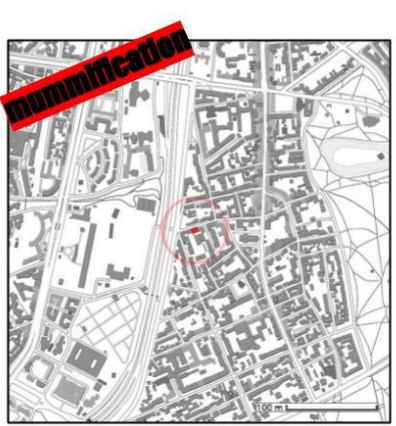

Social and spatial homogeneity

\section{DYNAMIC LAYERED URBAN CENTERS}

Figure 12. Summary 2.

Figure 13. Summary 3.
In the same way, gentrified morphologies are not a problem, providing the public realm is well thought after and managed. There is a consensus about what qualifies good urban places such as accessibility, connectivity, variety, adaptability, versatility, legibility, active spaces, human needs, sustainability, and urban landscaping. What is interesting to see here is that the urban morphology can vary as well as the social features, yet the place still feels like home.

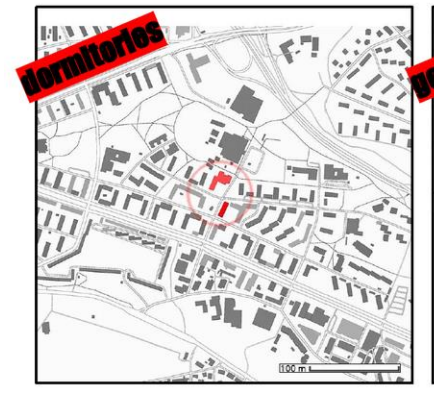

Social and spatial homogeneity

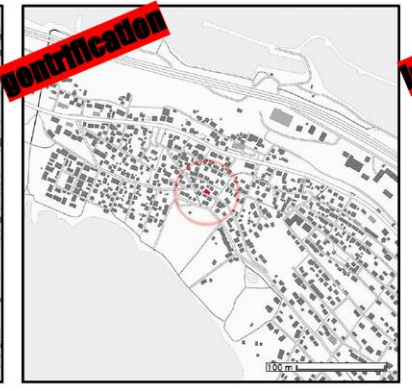

Social diversity and spatial homogeneity

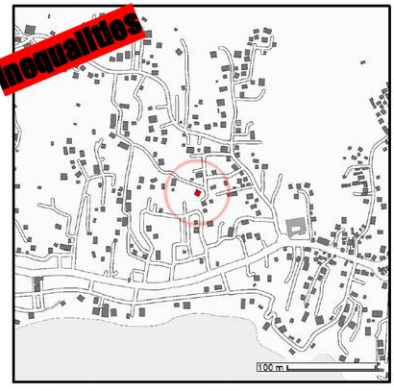

Social homogeneity and spatial development
OTHERNESS...REALLY?

Thirdly, I have developed a reading grid that is inspired by the six principles of Crime Prevention Through Environmental Design (QG, 2007). These principles are territoriality ("people's sense of control that others will not transgress or trespass on 'their territory' without invitation"), ownership (for the surrounding public realm), legibility (or wayfinding), surveillance, management, vulnerability. They are part of guidelines for urban design, commonly used in Australia, and derived from Jane Jacobs' focus on safety within cities, 'eyes on the street' (1961), and further developed by Newman in the 1970s with Defensible space (1972).

Methodologically, I have marked each of my successive homes according to the six principles on a score of 100 (100 being the maximum). It shows some interesting results (Figure 14). For example, regarding territoriality, Finland gets the lowest score, which could be culturally explained (not a long tradition of fencing in open plan housing). Ownership logically evolved throughout time with 
my financial capacity and growing activism. Surveillance came as a surprise because it revealed that Gosier and Saint Ouen l'Aumône got the top marks. However it seems logical as it demonstrates the role of people in controlling the environment, as well as that of good design to facilitate it. Legibility shows the evolution of complexity in my life trajectory: from very simple as a kid to more complex later on, as codes are being understood and territory of investigation expands. Management never succeeded to reach a maximum whatever the city, which seems normal: we are all aware of elements that could be improved in our built environment. Logically, cities with the least developed urban structures got the lowest score. Vulnerability also displays some ambiguous results are high scores were given for obvious reasons (social insecurity, high level of crime in Gosier, Vitry, Saint Ouen l'Aumône, even though I did not personally experience them) but also for less obvious ones such as lack of empathy (I witnessed too many times the fall and hurt of someone in the street of Tampere with no one caring) or direct violence (the attack of my daughter in Strasbourg, as well as many reports from my students). Clearly there are some limitations to the scores as it relies on the input of one person, but I still believe it is relevant in the context of this narrative research. Of course, it would be an interesting project to have many other people scoring these cities to see whether the results align with mine.

\section{Territoriality, Ownership, Surveillance, Legibility, Management \& Vulnerability}

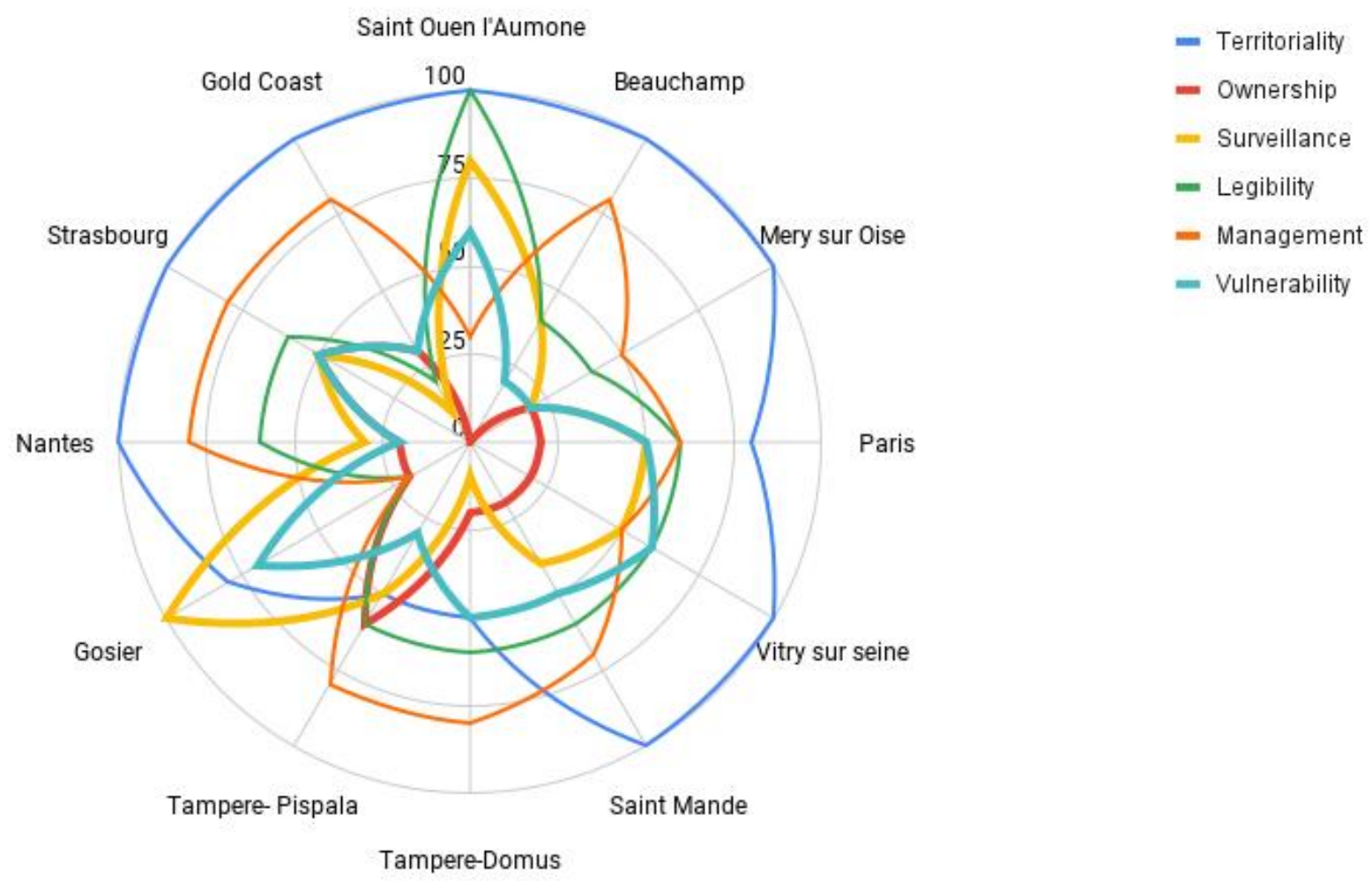

Figure 14. Reading grid from CPTED.
At last, I have tried to measure my attachment to all the different places I described earlier, in comparing home attachment versus city attachment. Why would I do that? Because I am convinced that architecture is not only the authored design of spaces we live in, but rather a discipline that organizes our bodies in space and facilitates the building of care, feelings and memories. Within this context, I agree with Massumi (2002), that our affect actually occurs prior to any understanding and meaning we might give. In that sense, attachment cannot only be explained by Nolli maps and reading grid; emotions are also involved. For example, Maurice Halbwachs, in his work On Collective Memory (1992), 
efficiently demonstrated the attachment to places that might not exist anymore and moreover, might not even be considered so great by today's standards. Affect is an implicit process in the creation of values.

Therefore it is not surprising that my house in Pispala is the biggest winner regarding home attachment, because it is mine. I have heavily sweated to fix it with Pasi and friends, and most importantly, this is where our two first children grew up and where we have built so many memories. Regarding which city I feel most attached to, it is quite impossible for me to choose. I know exactly which ones I am really not attached to, but basically, as soon as there is good walkability, minimum services for my children, mixed uses when I stroll here and there, opportunities such as a new theater play, a street demonstration, etc, I am happy. So again, it is not surprising that Paris, Nantes, Tampere arrived all equally on the top of my list.

However, there is another little town with none of these features that came at the same ranking: Le Gosier. Why? Because the place talked to my sense of aesthetics! Because of the oral culture and the music! Because of the harsh weather! Because I felt I could contribute! Because of the risk as well, to some extent: I had a feeling that the unexpected could happen and I felt like an adventurer. More recently, I visited New Orleans for the first time and it provided me with exactly the same feelings. The irrational me got very very excited!

So in conclusion, again, this is my personal journey and I know Pasi might have a very different perspective on these different places. For example, I know he is dreaming to live in Marseille, a coastal city south of France we once visited, and I am not, because I have sensed urban violence and roughness where he could only see nice urbanscapes.

The trends that have been described were presented in chronological order, like snapshots. For me, integration and safety were the focuses I experienced in France; social isolation in Finland; ageing and healthy city, resilience and climate change in Australia. These trends and the way I presented them don't reflect how they evolved since I left.

I also know I am a Privileged Nomad, to borrow a term coined by Pels (1999) in another context. My life is an easy one, without much financial hardship and many privileges to take advantage of. Knowing that, I don't think it makes my story less valuable, but represents a certain type of population and lifestyle. It certainly questions life journeys and their relationships to the city we inhabit.

So what makes architecture and city a home? Personally, I would define four aspects. Firstly, landmarks one can recognise. Secondly, places that are familiar (also by all senses such as smell and sound) and that we feel safe in. Thirdly, memories that we build into these places, in the same way that I am convinced that architecture builds memories, not only places. At last, this little thing that is so personal and that manages to talk to each of us individually: something in the air that appeals to who you are, and/or who you want to be.

\section{Credit illustrations}

All urban fabric maps after Google Maps @) Abuseif

Figure 1: archival pictures of the housing complex @ SOAinfo 2016

Figure 2: photograph of the housing complex @ Google and class picture @ personal collection.

Figure 3, 6, 7, 8, 9, 10,14: (C) author

Figure 4, 5: @ Google 


\section{References}

Benjamin, D. 1995. 'Afterword'. In: D. Benjamin and D. Stea, (Eds), The Home: Words, Interpretations, Meanings and Environments. Ethnoscapes: Current Challenges in the Environmental Social Sciences. Avebury, Aldershot.

Bosman, C., Dedekorkut-Howes, A., Leach, A. 2016. Off the PLan: the urbanisation of the Gold Coast, CSIRO Publishing.

Bourdieu, P. 1979. La Distinction. Critique sociale du jugement, Paris: Les Editions de Minuit.

Carless, D. and Douglas, K. 2016. "Narrative research", The Journal of Positive Psychology, Vol 12 (3).

Halbwachs, M. 1992. On Collective Memory. Translated from Coser, Heritage of Sociology Series.

INSEE, www.insee.fr, accessed December 2019.

Jacobs, J. 1961. The Death and Life of Great American Cities. New York: Random House.

Lawrence, R. 1995. "Deciphering home: an integrative historical perspective". In: D. Benjamin and D. Stea, (Eds), 1995. The Home: Words, Interpretations, Meanings and Environments. Ethnoscapes: Current Challenges in the Environmental Social Sciences. Avebury, Aldershot.

Le Corbusier, 1924. Urbanisme,Paris: G. Crès \& Cie.

Lieblich, A.; Tuval-Mashiah, R. and Zilber, T. 1998. Narrative research: reading, analysis and interpretation. Thousand Oaks, Calif.; London: SAGE.

Lynch, K. A. 1960. The Image of the City, Cambridge MA: MIT Press. Massumi Parables, B. 2002. For the Virtual: Movements, Affect, Sensation, Duke University Press, Durham NC.

Moore, J. 2000. "Placing home in context", Journal of Environmental Psychology, Vol.20 (3), pp. 207-217.

Newman, O. 1996. Creating Defensible space. US Dpt Housing \& Urban Development, Washington.

OMA, Koolhaas, R. and Mau, B. 1995. S, M, L, XL, 010 Publishers, Rotterdam, and Monacelli Press, Inc., New York.

Pels, D. 1999. Privileged Nomads: On the Strangeness of Intellectualls and the Intellectuality of Strangers, Theory, Culture and Society.

Queensland Government (QG) 2007. Crime Prevention through Environmental Design, Brisbane: State of Queensland.

Saunders, P. 1989. "The Meaning of 'Home' in Contemporary English Culture", Housing Studies 4(3), pp. 177-192.

Sixsmith, J. 1986. "The Meaning of Home: An Exploratory Study of Environmental Experience”, Journal of Environmental Psychology, Vol. 6, no. 4, pp. 281-298. 
Smith, S. G. 1994. "The Essential Qualities of a Home", Journal of Environmental Psychology, Vol. 14, no. 1, pp. 31-46.

SOAinfo 2016, Journal d'informations municipales 353, Saint Ouen L'Aumône, http://www.ville-saintouenlaumone.fr/sites/default/files/soa353.pdf, accessed November 2019.

Somerville, P. 1997. "The social construction of home", Journal of Architectural and Planning Research, 14(3), pp. 226-245.

Vitry94, Service Archives-Documentation, L'urbanisation de Vitry-sur-Seine, http://www.vitry94.fr/la-ville-cadre-de-vie/histoire-et-patrimoine/histoire/lurbanisa tion-de-vitry-sur-seine/, accessed November 2019. 